Jurnal Abdidas Volume 2 Nomor 1 Tahun 2021 Halaman 157-160

JURNAL ABDIDAS

http://abdidas.org/index.php/abdidas

PNIVERSITAS

\title{
Penggunaan Teknologi dalam Pelatihan Pembuatan Sabun sebagai Upaya Pemberdayaan Santri Pesantren Darussalam - Sumenep di Masa Pandemi Covid-19
}

\author{
Widhyasmaramurti $^{1}$, Khanifah ${ }^{2}$, Yuni Krisyuningsih Krisnandi ${ }^{3}$ \\ Fakultas Ilmu Pengetahuan Budaya, Universitas Indonesia, Indonesia ${ }^{1,2}$ \\ Fakultas Matematika dan Ilmu Pengetahuan Alam, Universitas Indonesia, Indonesia ${ }^{3}$ \\ E-mail: widhyasmaramurti.s@ui.ac.id ${ }^{1}$,khanifah@ui.ac.id ${ }^{2}$, ykrisna@ui.ac.id ${ }^{3}$
}

\begin{abstract}
Abstrak
Pandemi Covid-19 yang melanda seluruh dunia berimbas ke berbagai ranah kehidupan masyarakat. Efek Covid-19 juga dirasakan oleh para santri Pesantren Darussalam Sumenep. Di masa pandemi ini, para santri dihadapkan pada pilihan kembali ke rumah atas desakan ekonomi, atau tetap bertahan di pesantren. Santri yang bertahan di pesantren perlu mematuhi protokol kesehatan yaitu mencuci tangan, memakai masker dan menjaga jarak. Hal ini menyebabkan kebutuhan sabun dalam lingkungan pesantren meningkat. Maka pelatihan pembuatan sabun dilakukan dengan tujuan sebagai upaya pemberdayaan masyarakat untuk mendukung pencegahan Pandemi Covid-19 dalam lingkup pesantren, namun tetap memiliki nilai ekonomi di saat yang bersamaan. Adanya Pembatasan Sosial Berskala Besar (PSBB) di daerah-daerah di Indonesia tidak membuat pelatihan pembuatan sabun terhenti karena teknologi tepat guna digunakan sebagai alternatif pelatihan pembuatan sabun. Pelatihan secara sinkronus dengan menggunakan platform Zoom, video demonstrasi pembuatan sabun yang terakses melalui media daring seperti YouTube, serta pendampingan kontinu oleh koordinator lapangan menjadi alternatif pelatihan di masa pandemi ini. Kurang stabilnya akses jaringan internet menjadi tantangan yang ditindaklanjuti melalui forum diskusi (chat) menggunakan WhatsApp. Proses evaluasi menggunakan Focus Group Discussion (FGD) dan Google Form menjadi sarana melihat indikator keberhasilan. Hasil pengabdian masyarakat ini ada dua, yaitu: 1) tertransfernya pengetahuan pembuatan sabun melalui teknologi tepat guna, 2) terbentuknya komunitas santri yang mampu memproduksi sabun. Walaupun produksi sabun masih bersifat untuk konsumsi internal pesantren, namun santri Pesantren Darussalam diharapkan mampu membangun jaringan penjualan sabun sebagai upaya peningkatan ekonomi mereka. Pemberdayaan masyarakat ini juga diharapkan dapat membentuk komunitas santri yang mampu mendukung pemerintah dalam upaya mencegah Covid-19.
\end{abstract}

Kata kunci: Covid-19, pembuatan sabun, pelatihan daring, Pesantren Darussalam, Sumenep

\begin{abstract}
The Covid-19 pandemic has affected many scopes of people's lives. The effects of Covid-19 were also felt by the students (santri) of Islamic boarding school (pesantren) Darussalam, Sumenep. During this pandemic, they are facing the choices of returning home due to economic pressure, or staying in the pesantren. The santri who stay in the pesantren need to adhere to health protocols, namely washing hands, wearing masks and maintaining distance. This causes the need for soap to increase. Therefore, the soap making workshop was conducted with the aim of empowering santri community to support the prevention of the Covid-19 but still having economic value at the same time. The Large-Scale Social Restrictions (PSBB) in Indonesian regions has turned this workshop into an online one by using appropriate technology. This workshop used synchronous training by Zoom platform, a YouTube video demonstration, and continuous assistance by a field coordinator. The lack of stable internet network is a challenge which has been overcome by using a discussion forum in WhatsApp group. The successful indicators were obtained from evaluation that used Focus Group Discussion (FGD) and Google Form. The results can be seen from the soap making knowledge transfer through appropriate technology, and the soap production of the santri community. Eventhough the soap is still for internal consumption, but the santri are hopefully able to build a soap sales network as an effort to improve their economy as well as able to support Indonesian government in preventing the Covid-19.
\end{abstract}

Keywords: Covid-19, hand made soap, online workshop, Pesantren Darussalam, Sumenep

Copyright (c) 2021 Widhyasmaramurti, Khanifah, Yuni Krisyuningsih Krisnandi

$\square$ Corresponding author

Address : Universitas Indonesia

Email : widhyasmaramurti.s@ui.ac.id

ISSN 2721- 9224 (Media Cetak)

DOI : https://doi.org/10.31004/abdidas.v2i1.232

ISSN 2721- 9216 (Media Online) 
158 Penggunaan Teknologi dalam Pelatihan Pembuatan Sabun sebagai Upaya Pemberdayaan Santri Pesantren Darussalam - Sumenep di Masa Pandemi Covid-19- Widhyasmaramurti, Khanifah, Yuni Krisyuningsih Krisnandi

DOI: https://doi.org/10.31004/abdidas.v2i1.232

\section{PENDAHULUAN}

COVID-19 yang menjadi pandemi di seluruh dunia sejak mulai berkembang pertama kali di awal tahun 2020, sepertinya belum menunjukkan akan mereda dalam waktu dekat. Dengan jumlah kasus sebanyak 106.125.682 di seluruh dunia (Covid19.go.id, 2021), serta jumlah pasien positif 1.174 .779 di Indonesia, Covid-19 yang termasuk dalam galur dari tipe virus yang disebabkan oleh severe acute respiratory syndrome coronavirus 2 (SARS-CoV-2) atau biasa dikenal sebagai coronavirus, bukanlah virus yang dapat dianggap enteng. Terlebih jumlah korban meninggal dunia di Indonesia telah berjumlah 31.976 jiwa per tanggal 9 Februari 2021 ini (Covid19.go.id, 2021). Angka korban jiwa tersebut masih terus bertambah karena masih banyaknya masyarakat yang belum sadar akan pentingnya menjaga kesehatan di tengah pandemi Covid-19 ini. Proses penularan virus ini terjadi melalui kontak fisik dengan penderita. Secara tidak disadari, penderita COVID-19 dapat menularkan dari satu orang ke orang yang lainnya melalui tetesan lendir dari hidung ataupun mulut saat mereka bersin tanpa tertutupi oleh masker. Saat terinfeksi, orang dengan coronavirus ini dapat diawali demam, diare, hingga sesak nafas. Proses inkubasi selama 2-14 hari setelah terpapar menyebabkan penderita umumnya tidak sadar bahwa mereka adalah pembawa virus yang dapat membahayakan orang lain. Pasien yang dirasa memiliki kondisi cukup parah, mereka perlu dirawat secara intensif di rumah sakit, sedangkan pasien yang dirasa memiliki gejala ringan, bahkan tidak merasakan gejala apapun walaupun sudah melakukan tes swab PCR (polymerase chain reaction) dengan hasil yang positif, maka mereka dapat melakukan isolasi mandiri (Pranita, 2021). Kondisi pandemi Covid-19 yang belum berangsur usai ini berefek pada menurunnya perekonomian rakyat (Setiawan, 2020). Hal ini pula yang melatarbelakangi pengabdian masyarakat (pengmas) yang berfokus kepada pendampingan para santri di Pesantren Darussalam, Desa Daja Songai, Kelurahan Billapora Timur, Kecamatan Ganding, Sumenep, Jawa Timur. Pesantren Darussalam yang terletak di Desa Daja Songai ini berjarak sekitar 18 kilometer dari pusat Kabupaten Sumenep. Dengan luas daerah kabupaten sebesar 2.093,47 Kilometer persegi (Km2) di tahun 2018 (Sumenepkab.bps.go.id, 2018) dan jumlah penduduk sebesar 1.124.436 jiwa berdasarkan sensus tahun 2020, Kabupaten Sumenep merupakan daerah dengan bonus demografi yang cukup baik karena $72,32 \%$ penduduknya masih bersifat produktif (usia 15-64 tahun) (Sumenepkab.bps.go.id, 2021), dan terbuka untuk perkembangan perekonomian wilayah. Kemudian, dengan Produk Domestik Bruto (PDB) Kabupaten Sumenep dalam jutaan rupiah sebesar 23.770,320, 32 di tahun 2019 (Sumenepkab.bps.go.id, 2019), maka bisa dikatakan jika performa Kabupaten Sumenep sebagai salah satu kabupaten di Jawa Timur dalam sektor ekonomi cukup baik walaupun tidak bisa dikatakan superior seperti PDB Kota Surabaya yang mencapai 554,59 triliun rupiah (Kurniawan, 2020). Oleh sebab itu, pendampingan kepada para santri Pesantren Darussalam 
159 Penggunaan Teknologi dalam Pelatihan Pembuatan Sabun sebagai Upaya Pemberdayaan Santri Pesantren Darussalam - Sumenep di Masa Pandemi Covid-19- Widhyasmaramurti, Khanifah, Yuni Krisyuningsih Krisnandi

DOI: https://doi.org/10.31004/abdidas.v2i1.232

diharapkan dapat menjadi secercah warna dalam meningkatkan perekonomian daerah nantinya.

Tujuan pendampingan program Pengabdian Masyarakat (Pengmas) ini adalah berupaya memberikan pengetahuan yang dapat bermanfaat bagi para santri sekaligus bernilai ekonomi. Maka sebab itu, perlu kiranya melihat kompleksitas santri di Pesantren Darussalam terlebih dulu. Hal ini karena kondisi para santri di Pesantren Darussalam yang memang berasal dari golongan menengah ke bawah, maka di masa pandemi Covid-19 ini, mereka mengalami tantangan dalam kegiatan belajar mengajar. Di masa pandemi ini, terdapat tiga kategori jenis santri. Pertama, santri yang diminta pulang oleh orang tuanya ke rumah. Mereka pulang dengan pertimbangan demi kesehatan. Pilihan untuk tinggal di rumah dirasa jauh lebih aman dibandingkan jika berdiam di pesantren, dimana mereka akan terus bersinggungan dengan banyak orang. Mereka yang diminta pulang oleh keluarga untuk pulang ke rumah akan melanjutkan proses belajar mengajar secara daring dengan menggunakan gawai. Sistem belajar di rumah ini sudah disarankan oleh pemerintah sejak pandemi berkembang di Indonesia di bulan Maret 2020 (Kemendikbud, 2020). Kedua, santri yang diminta pulang ke rumah karena orang tua mengalami keterbatasan ekonomi di masa pandemi. Santri tipe ini umumnya tidak akan kembali ke pesantren dalam waktu dekat dan cenderung tidak melanjutkan pendidikan. Bagi santriwati, kebanyakan juga berpotensi untuk dinikahkan di usia dini mengingat praktik pernikahan dini masih banyak terjadi di Sumenep. Ketiga, santri yang tetap tinggal di pesantren karena jarak rumah yang jauh dari pesantren. Selain itu, santri yang tetap tinggal ini umumnya juga beranggapan bahwa pandemi tidak seharusnya menghalangi kegiatan di pesantren karena meskipun pembelajaran daring bisa dilakukan sebagai pengganti, namun kendala seperti keterbatasan gawai dan susahnya koneksi internet membuat mereka lebih memilih untuk menetap di pesantren saja selama pandemi. Santri yang menetap di pesantren adalah santri yang memiliki ketertarikan untuk ikut ambil bagian sebagai peserta kegiatan pengabdian masyarakat ini. Kegiatan utama yang dilakukan untuk mendukung pencegahan Covid-19 di lingkungan Pesantren Darussalam dan memiliki nilai ekonomi adalah pelatihan pembuatan sabun. Oleh sebab itu, fokus Pengmas ini adalah bagaimana proses transfer pengetahuan kepada para santri agar mereka dapat memahami dan memproduksi sabun yang dapat mereka gunakan di masa pandemi Covid-19 ini? Serta bagaimana pemberdayaan santri dapat meningkatkan kesadaran mereka akan pentingnya hidup sehat dan dapat meningkatkan perekonomian mereka di masa pandemi berlangsung?

Sabun dalam daftar Standar Nasional Indonesia (SNI) memiliki nomer 06-3532-1994 (Sispk.bsn.go.id, 2021). Di tengah masyarakat, sabun dapat berbentuk padat (hard soap) maupun cair (soft soap), dan umumnya digunakan sebagai bahan untuk membersihkan peranti kehidupan sehari-hari. Pengmas pelatihan pembuatan sabun ini bertujuan untuk mendukung para santri di mana 
160 Penggunaan Teknologi dalam Pelatihan Pembuatan Sabun sebagai Upaya Pemberdayaan Santri Pesantren Darussalam - Sumenep di Masa Pandemi Covid-19- Widhyasmaramurti, Khanifah, Yuni Krisyuningsih Krisnandi

DOI: https://doi.org/10.31004/abdidas.v2i1.232

saja mereka berada (di pesantren maupun di rumah) untuk dapat memproduksi sabun dengan bahan yang mudah ditemukan sehari-hari di lingkungan mereka. Oleh sebab itu, bahan pembuatan sabun yang digunakan dalam pelatihan ini dipilih sesederhana mungkin, sehingga para santri nantinya dapat menyediakan sendiri bahanbahan yang diperlukan apabila mereka hendak mengembangkan usaha sabun secara mandiri. Tiga bahan utama yang diperlukan adalah sebagai berikut:

Tabel 1. Bahan Utama Sabun

\begin{tabular}{|c|l|c|}
\hline No & \multicolumn{3}{|c|}{ Bahan } & $\begin{array}{c}\text { Jumlah } \\
\text { (massa } \\
\text { atau } \\
\text { volume) }\end{array}$ \\
\hline 1. & $\begin{array}{l}\text { Soda Api atau Soda Kaustik } \\
\text { (Natirum Hram }\end{array}$ & 80 Hroksida atau NaOH) \\
\hline 2. & $\begin{array}{l}\text { Air atau Aquades yang Bebas } \\
\text { Klorin atau Kaporit }\end{array}$ & $300 \mathrm{ml}$ \\
\hline 3. & $\begin{array}{l}\text { Senyawa Asam Lemak atau } \\
\text { Minyak }\end{array}$ & $500 \mathrm{ml}$. \\
\hline
\end{tabular}

Komposisi di atas adalah untuk minyak per $500 \mathrm{ml}$. Tentu saja, ukuran minyak yang berubah akan mengubah komposisi bahan yang lainnya. Oleh sebab itu, ukuran 3 bahan di atas berlaku sesuai kelipatan. Selain 3 bahan di atas, sabun juga dapat ditambahkan bahan lain seperti zat pewarna dan pewangi. Hal yang perlu diperhatikan saat membuat sabun ada 2, yaitu: 1) proses pelarutan $\mathrm{NaOH}$ ke aquades 'air'; dan 2) proses penggabungan larutan $\mathrm{NaOH}$ dan larutan senyawa minyak. Untuk proses pelarutan $\mathrm{NaOH}$, air disiapkan terlebih dahulu di dalam bejana/tempat tertentu sebelum memasukkan $\mathrm{NaOH}$ agar mencegah terjadinya percikan $\mathrm{NaOH}$ yang tidak diinginkan karena dapat membahayakan bila terkena kulit dan mata. Proses pelarutan ini akan menyebabkan temperatur larutan menjadi meningkat (panas). Maka, untuk penggabungan larutan $\mathrm{NaOH}$ dan senyawa minyak, perlu dipastikan jika temperatur kedua larutan berada pada suhu yang sama. Widyasanti, Putri, Dwiratna (2016) menyatakan jika proses pembuatan sabun dilakukan dengan dengan dua cara yaitu: 1) proses saponifikasi, dan 2) proses netralisasi minyak. Senyawa asam lemak yang larut bersamaan dengan soda kaustik/ natirum hidroksida $(\mathrm{NaOH})$ akan memproduksi sabun padat (hard soap), sedangkan sabun cari (soft soap) dihasilkan dari penggabungan antara senyawa lemak dengan garam kalium hidroksida $(\mathrm{KOH})$ dalam Widyasanti et al. (2016: 29-30). Walau demikian, proses pembuatan sabun di Pengmas kali ini lebih mengacu kepada pembuatan sabun padat terlebih dahulu. Setelah sabun padat selesai, maka proses pembuatan sabun cair, yang merupakan proses lanjutan dari sabun padat dapat dilakukan. Di mana sabun padat akan diparut dan dipanaskan bersama aquades untuk menghasilkan sabun cair. Proses ini diharapkan menjadi proses pembuatan sabun sederhana yang dapat dipahami oleh para santri dan santri fasilitator yang hendak mengembangkan pengetahuan mereka bagi masyarakat di sekitar pesantren.

Dalam proses pendampingan ini, karena adanya pembatasan aktivitas antar wilayah serta himbauan dari pemerintah, baik nasional maupun lokal untuk tidak melakukan perjalanan luar kota demi mencegah penyebaran Covid-19, maka 
161 Penggunaan Teknologi dalam Pelatihan Pembuatan Sabun sebagai Upaya Pemberdayaan Santri Pesantren Darussalam - Sumenep di Masa Pandemi Covid-19- Widhyasmaramurti, Khanifah, Yuni Krisyuningsih Krisnandi

DOI: https://doi.org/10.31004/abdidas.v2i1.232

kegiatan pelatihan pembuatan sabun ini dilakukan secara daring dengan menggunakan pemanfaatan teknologi tepat guna yang dapat diakses oleh para santri di Pesantren Darussalam. Teknologi tepat guna yang digunakan untuk proses pengajaran daring yang banyak dipergunakan di tengah masyarakat saat ini juga digunakan dalam konferensi daring, dan umumnya merupakan platform video conference. Seiring dengan perkembangan zaman, teknologi video conference semakin berkembang sehingga sekarang ini ada Google Meet, Ms-team, Zoom, Face Time, dan Visco Webex (Hanifah et al., 2020). Akan tetapi, platform untuk belajar mengajar tidak terbatas hanya melalui video conference saja. Saat ini juga banyak platform yang mendukung proses kegiatan belajar mengajar secara daring non-video conference seperti Google Classroom, Edmodo, Moodle (Hanifah et al., 2020), serta e-learning yang dikembangkan oleh masing-masing institusi pendidikan. Bahkan platform komunikasi daring seperti WhatsApp dan Telegram, juga banyak digunakan karena dalam penggunaannya tidak menyedot banyak kuota maupun pulsa gawai. Banyaknya pilihan platform, memudahkan dalam memilih platform yang sesuai untuk kegiatan ini. Dengan mempertimbangkan konektivitas yang terbatas, maka dipilihlah Zoom karena memiliki kestabilan dalam penayangan video. Hal ini sesuai dengan penjelasan CFO Zoom, Kelly Steckelberg, yang menyatakan jika Zoom memiliki keandalan karena jarang down dan memiliki latency yang rendah, sehingga tetap mampu menampilkan video dan audio yang berkualitas walaupun koneksi internet tidak stabil (Pratama, 2020). Jaringan internet untuk melakukan video conference di Pesantren Darussalam tidak stabil. Dari 5 provider nasional yang dominan di Indonesia, yaitu Telkomsel, XL, Indosat, 3, dan Smartfren (Kurnia, 2018), dalam aplikasinya di Pesantren Darussalam, hanya Indosat yang bisa digunakan dengan hasil speedtest sebesar 2.39 Mbps, sedangkan 4 provider lainnya tidak dapat akses jaringan di lokasi pesantren. Kecepatan 2.39 Mbps tersebut sebenarnya dapat melakukan video conference, namun dengan kualitas gambar yang standar karena kecepatan yang bagus untuk melakukan video conference dengan kualitas yang baik adalah 10-20 Mbps (Ashari, 2018). Walau demikian, kendala jaringan internet yang terbatas tidak menghalangi proses kegiatan Pengmas pelatihan pembuatan sabun ini.

Pengmas pelatihan pembuatan sabun dipilih karena penggunaannya yang bermanfaat di tengah masa pandemi ini dan memiliki nilai ekonomi karena dapat diperjualbelikan. Tujuan jangka pendek dari pelatihan ini adalah menghasilkan sabun-sabun yang dapat mendukung kebiasaan hidup sehat dengan rajin mencuci tangan untuk mencegah menyebarnya penularan Covid-19. Kemudian, tujuan jangka panjang dari pelatihan pembuatan sabun adalah menghasilkan produk sabun yang dapat diperjualbelikan untuk meningkatkan perekonomian para santri di masa pandemi ini dengan menjualnya melalui sistem jaringan komunitas masyarakat di sekitar pesantren, maupun mencoba untuk dijual secara daring melalui marketplace yang dapat diunduh 
162 Penggunaan Teknologi dalam Pelatihan Pembuatan Sabun sebagai Upaya Pemberdayaan Santri Pesantren Darussalam - Sumenep di Masa Pandemi Covid-19- Widhyasmaramurti, Khanifah, Yuni Krisyuningsih Krisnandi

DOI: https://doi.org/10.31004/abdidas.v2i1.232

dalam bentuk aplikasi digital yang dapat diakses secara mudah melalui gawai. Outcome kegiatan yang dapat terukur adalah penambahan pengetahuan para santri dari yang sebelumnya tidak tahu sama sekali tentang proses pembuatan sabun menjadi paham dan mampu memproduksi sabun, serta hasil produksi sabun yang dapat dimanfaatkan oleh para santri baik untuk keperluan internal dalam lingkungan pesantren maupun eksternal sebagai komoditas yang dapat meningkatkan ekonomi santri.

\section{METODE}

Metode pengabdian yang dilakukan adalah participatory approach atau metode partisipasi. Pemilihan metode partisipasi dipilih karena dapat langsung berhubungan dengan masyarakat, sehingga mereka dapat langsung turut aktif berperan serta dalam kegiatan pengabdian masyarakat mulai dari perencanaan kegiatan, pelaksanaan kegiatan (aksi) hingga pengembangan kegiatan (Hudayana et al., 2019). Oleh sebab itu, proses Pengmas dilakukan dengan menitikberatkan keaktifan dari komunitas santri Pesantren Darussalam. Untuk lebih memastikan jika peserta dapat menerima materi pelatihan yang diberikan, maka peran koordinator lapangan dibutuhkan sebagai mediator antara peserta pelatihan (santri) dan pemateri pelatihan. Adapun metode pelaksanaan Pengmas terbagi atas prapelatihan, pelatihan pembuatan sabun, dan pascapelatihan. Tiga tahapan dilakukan untuk mencapai tujuan pelatihan dan memperoleh outcome yang diharapkan.
Prapelatihan difokuskan kepada survei untuk mencari tahu kebutuhan Pesantren Darussalam, kondisi para santri, ketersediaan sarana dan prasarana lokal, dan memberikan pemahaman akan perlunya partisipasi aktif dari segenap komunitas pesantren Darussalam mulai dari para santri, santriwati, guru, dan pengurus aktif santri. Setelah mendapatkan informasi akan kebutuhan santri dan informasi ketersediaan sarana dan prasarana, pada tahapan ini juga dilakukan pematangan persiapan pembuatan materi pelatihan, agenda pembuatan video, dan mendiskusikan teknologi yang sesuai sebagai media penayangan video pelatihan.

Pelatihan pembuatan sabun dilakukan secara sinkronus sesuai waktu yang disepakati. Tahapan ini terbagi dua yaitu pertama tahapan penyampaian materi pelatihan, dan tahapan yang kedua adalah praktik pembuatan sabun. Tahapan kedua membutuhkan peran koordinator lapangan yang memantau berjalannya proses praktik pembuatan sabun, mulai dari penghitungan bahan, pencampuran bahan, pencetakkan sabun, hingga pengemasan sabun yang telah jadi. Pascakegiatan lebih berfokus pada evaluasi kegiatan dan hasil sabun, serta pendampingan lebih lanjut untuk menindaklanjuti kegiatan pada fokus lanjutan yaitu kontinuitas produksi, penentuan harga pokok, dan pengembangan pemasaran hasil sabun.

\section{HASIL DAN PEMBAHASAN}

\section{Kegiatan Pra-pelatihan.}

Kegiatan ini meliputi beberapa hal sebagai berikut, yaitu: menjaring kebutuhan stakeholder 
163 Penggunaan Teknologi dalam Pelatihan Pembuatan Sabun sebagai Upaya Pemberdayaan Santri Pesantren Darussalam - Sumenep di Masa Pandemi Covid-19- Widhyasmaramurti, Khanifah, Yuni Krisyuningsih Krisnandi

DOI: https://doi.org/10.31004/abdidas.v2i1.232

(dalam hal ini adalah santri, dan pengurus Pesantren Darussalam), koordinasi kondisi di lapangan dengan koordinator lapangan, pembelian bahan baku, koordinasi penerimaan bahan, dan pembuatan video demonstrasi pembuatan sabun. Kegiatan prapelatihan ini lebih banyak dilakukan secara daring, sementara kegiatan di lapangan dikordinasikan melalui koordinator lapangan yang memastikan semua persiapan pelatihan sabun ini sesuai dengan yang diharapkan.

Penjajakan potensi desa dilakukan secara daring melalui Focus Group Discussion (FGD) kepada pihak pengurus Pesantren Darussalam untuk mendapatkan data mengenai kebutuhan pesantren yang disesuaikan dengan kondisi lapangan. Hal ini untuk melihat bahwa pendampingan akan sesuai dengan kebutuhan yang diharapkan, serta akan menghasilkan manfaat yang berguna bagi para santri Pesantren Darussalam dalam mendukung kemandirian mereka. Setelah penjajakan potensi desa selesai dilakukan, pembelian bahan baku kemudian dilakukan secara daring yang dikirimkan langsung ke Pesantren Darussalam. Bahan-bahan utama yang diperlukan untuk pembuatan sabun beserta peralatan yang digunakan untuk proses pembuatannya dikirimkan langsung ke alamat pondok pesantren Darussalam. Bahan-bahan dan peralatan ini kemudian diterima oleh koordinator lapangan untuk kemudian diinventarisir dan disiapkan untuk proses kegiatan selanjutnya. Pembuatan video tutorial membuat sabun juga dilakukan untuk didiseminasikan ke para peserta pelatihan membuat sabun secara daring. Proses pembuatan video demonstrasi

pembuatan sabun dilakukan di Fakultas Matematika dan Ilmu Pengetahuan Alam (FMIPA UI) di awal bulan Desember 2020. Demonstrasi menggunakan minyak sawit dan minyak jelantah atau minyak bekas pakai. Akan tetapi, pada video, disampaikan juga jika semakin bagus senyawa minyak yang digunakan, maka hasil sabun juga akan semakin baik. Setalah video demonstrasi selesai direkam, proses selanjutnya adalah proses pengeditan, di mana beberapa cuplikan video yang terpisah dirangkai menjadi satu kesatuan utuh untuk ditayangkan saat pelatihan daring. Video ini juga dapat diakses oleh peserta secara daring dari YouTube yang dapat dijadikan materi pelatihan yang dapat diakses kapan saja.

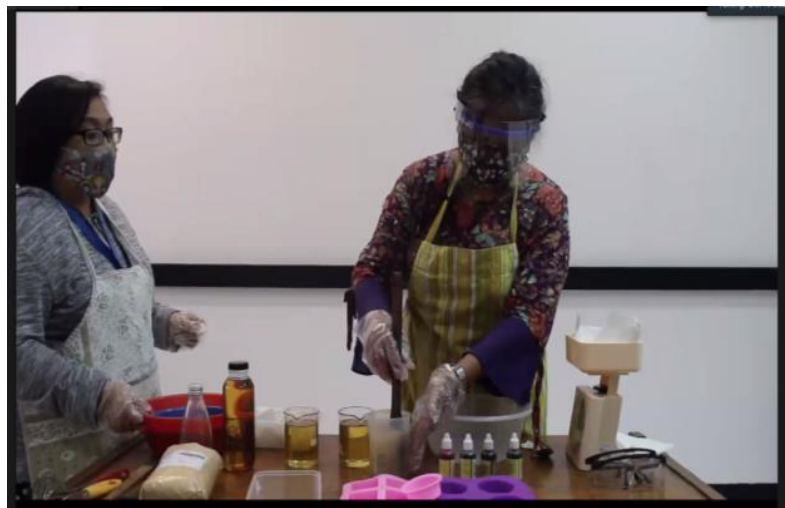

Gambar 1. Pembuatan Video Pelatihan

\section{Pelatihan Pembuatan Sabun}

Setelah penjajakan dilakukan, video pelatihan disiapkan, maka kegiatan selanjutnya adalah kegiatan inti yaitu pelatihan pembuatan sabun. Produk sabun yang dihasilkan dari pelatihan ini adalah pelatihan sabun kotak atau batangan dari minyak sawit. Pelatihan ini dilakukan di Pesantren Darussalam, Sumenep, Jawa Timur, selama 3 hari di pertengahan Januari 
164 Penggunaan Teknologi dalam Pelatihan Pembuatan Sabun sebagai Upaya Pemberdayaan Santri Pesantren Darussalam - Sumenep di Masa Pandemi Covid-19- Widhyasmaramurti, Khanifah, Yuni Krisyuningsih Krisnandi

DOI: https://doi.org/10.31004/abdidas.v2i1.232

2021. Kegiatan ini dilakukan setelah hasil sabun dari demonstrasi selesai secara sempurna dan sudah diuji coba. Dari awal proses pembuatan, sabun membutuhkan waktu 30 hari untuk menghilangkan efek $\mathrm{NaOH}$ secara perlahan, sehingga diperoleh hasil yang sempurna dan dapat dipergunakan dengan baik tanpa efek samping. Mengingat di masa pandemi Covid 19 ini, para santri dan santriwati Pesantren Darussalam diberikan kebebasan untuk belajar di pondok pesantren maupun belajar dari rumah, maka peserta pelatihan pun bersifat sukarela dan tidak diwajibkan. Dari seluruh santri dan santriwati di lingkungan Pesantren Darussalam yang berjumlah 60 orang, lebih dari 50 peserta yang mendaftar. Namun dengan memperhitungkan sistem operasional pelatihan yang tetap harus menjaga jarak, dan ruangan aula yang terbatas, maka peserta pelatihan yang dipilih oleh pihak pesantren hanya berjumlah 25 peserta, dan pelatihan dilakukan selama 3 hari secara daring pada 11-13 Januari 2021 dan praktik selama seminggu dari tanggal 14-21 Januari 2021. Pelatihan secara secara daring menggunakan platform Zoom diberikan kepada para santri dengan sistem diskusi yang diikuti dengan tanya jawab, serta simulasi untuk praktik membuat sabun. Praktik membuat sabun menggunakan 2 jenis minyak yaitu minyak sawit dan minyak jelantah. Untuk memberikan pemahaman yang lebih kepada peserta pelatihan, video pelatihan pembuatan sabun juga diunggah di media mainstream yang mudah diakses yaitu YouTube. Pemilihan media ini lebih kepada akses yang cepat karena setiap gawai android saat ini pasti memiliki platform YouTube, dan tidak banyak menyita kuota karena tidak perlu disimpan di dalam gawai, namun dapat disimpan dalam library pemilik akun YouTube, sehingga dapat ditonton setiap saat walaupun tidak mengaktifkan koneksi internet.

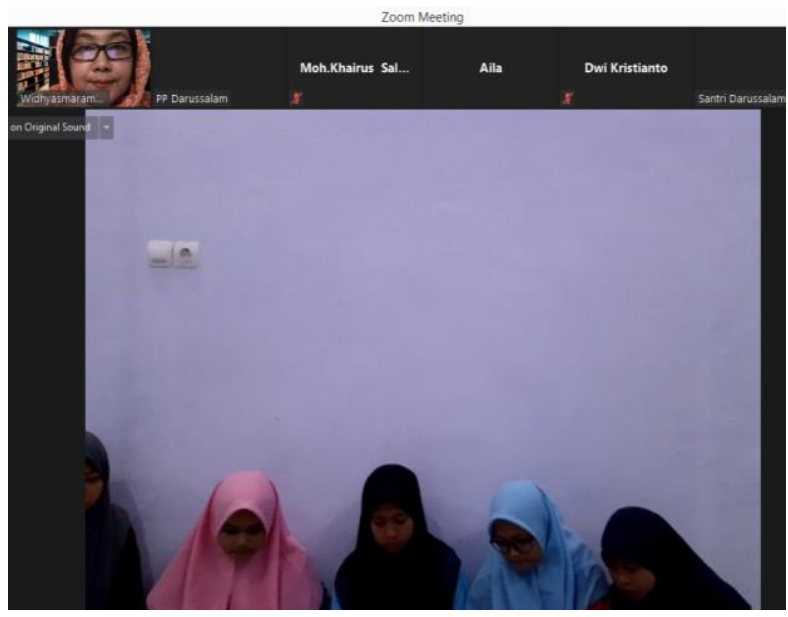

Gambar 2. Pelatihan Pembuatan Sabun

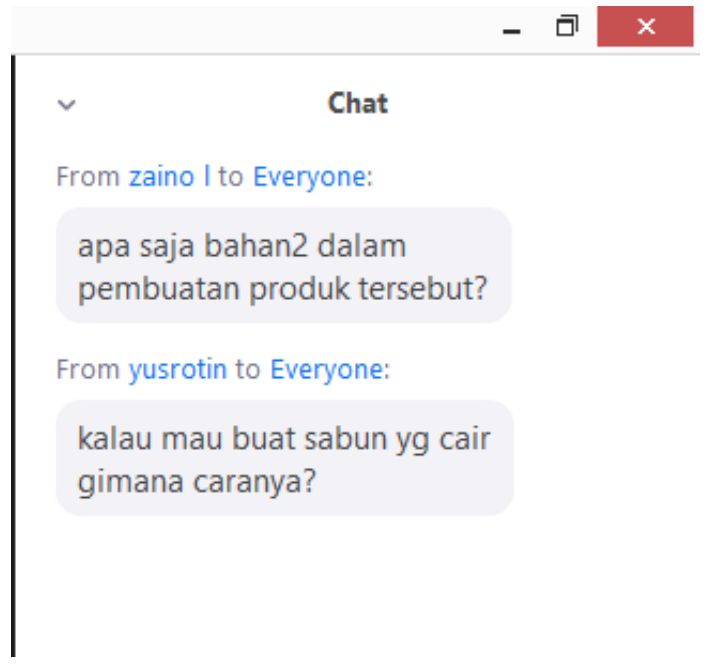

Gambar 3. Tanya Jawab Dilakukan Secara Langsung

Tantangan utama dalam proses pelatihan sabun yang adalah konektivitas jaringan yang tidak stabil di lokasi Pesantren Darussalam. Dalam melakukan proses pelatihan dengan menggunakan 
165 Penggunaan Teknologi dalam Pelatihan Pembuatan Sabun sebagai Upaya Pemberdayaan Santri Pesantren Darussalam - Sumenep di Masa Pandemi Covid-19- Widhyasmaramurti, Khanifah, Yuni Krisyuningsih Krisnandi

DOI: https://doi.org/10.31004/abdidas.v2i1.232

Zoom. Jaringan internet dari pihak pesantren kerap terputus sehingga proses pelatihan harus dilakukan secara perlahan agar mereka yang sempat terputus koneksinya dan sempat "terlempar keluar" dari ruang pertemuan Zoom dapat terhubung kembali, dan bertanya tentang proses yang terlewati. Tantangan lain adalah kurang aktifnya komunikasi dari para santri, serta cenderung untuk menerima materi yang diberikan, sehingga komunikasi terkesan satu arah. Walau demikian, ini lebih banyak dihadapi oleh para santriwati. Pelaksanaan pelatihan yang membagi antara santri dan santriwati membuat perbedaan yang muncul sangat jelas terlihat. Para santriwati yang cenderung pasif dan menerima membuat proses transfer pengetahuan tersebut menjadi sulit terukur. Untungnya keaktifan dari para santri dalam sesi tanya jawab baik secara langsung mapun tertulis membuat proses transfer pengetahuan menjadi lebih terukur. Tantangan selanjutnya yang perlu ditindaklanjuti adalah membantu para santri dalam proses pemasaran hasil sabun yang diharapkan dapat menjangkau pasar yang lebih luas. Maka tantangan Pengmas selanjutnya adalah perlunya melakukan riset tentang pasar, membentuk manajemen produksi, manajemen pemasaran, dan memilih penggunaan teknologi tepat guna yang diperlukan untuk mendukung proses pemasaran nantinya. Pelatihan pembuatan sabun ini juga menjadi tantangan dari para santri yang mengikuti pelatihan secara mandiri di rumah masing-masing. Mereka tidak kesulitan memahami materi secara mandiri namun kesulitan dalam mendapatkan bahan $\mathrm{NaOH}$ yang tidak mudah untuk dibeli di lingkungan tempat tinggal mereka. Akan tetapi, santri yang mampu memproduksi sabun secara mandiri di rumah masing-masih diharapkan dapat menjadi fasilitator dalam mengembangkan usaha sabun di lingkungan rumah mereka.
1) Melarutkan soda api ke 2) Mencampur larutan soda api dengan dalam air.

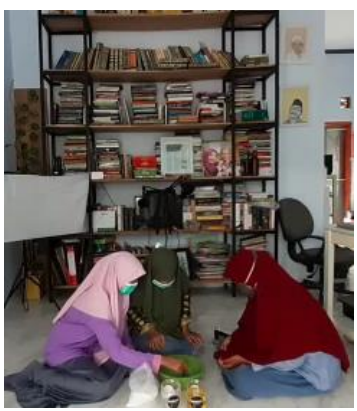
minyak saat kedua larutan sudah dalam suhu yang sama.

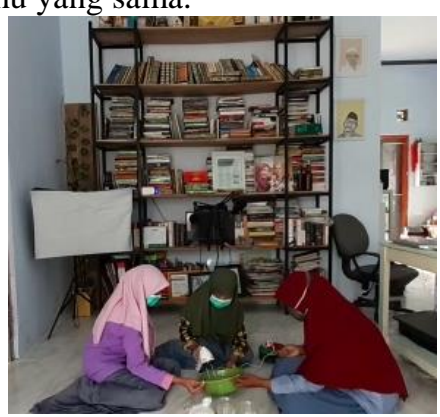

3) Mencetak adonan sabun. Sabun bisa digunakan setelah 30 hari.

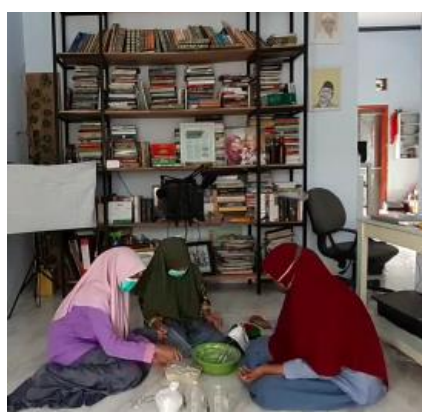

Gambar 4. Praktik Pelatihan secara Berkelompok oleh Santriwati Pesantren Darussalam

\section{Pasca Pelatihan}

Evaluasi kegiatan menjadi fokus dari kegiatan pascapelatihan. Evaluasi dilakukan untuk melihat seberapa jauh pelatihan pembuatan sabun dapat dipahami oleh para peserta. Evaluasi kegiatan menggunakan format FGD dan dibantu 
158 Penggunaan Teknologi dalam Pelatihan Pembuatan Sabun sebagai Upaya Pemberdayaan Santri Pesantren Darussalam - Sumenep di Masa Pandemi Covid-19- Widhyasmaramurti, Khanifah, Yuni Krisyuningsih Krisnandi

DOI: https://doi.org/10.31004/abdidas.v2i1.232

dengan Google Form untuk mengukur indikator keberhasilan kegiatan. FDG dilakukan dalam bentuk bincang ringan pada hari Minggu malam, 23 Januari 2021. Kegiatan dilakukan di hari Minggu malam karena santri yang pulang ke rumah di akhir pekan biasanya sudah kembali ke dalam lokasi pesantren di hari Minggu sore. FGD digunakan untuk memperoleh informasi pada proses evaluasi pelatihan secara daring, sedangkan Google Form yang berisi 14 pertanyaan seputar pelaksanaan pelatihan daring digunakan untuk mendapatkan informasi tentang evaluasi kegiatan yang lebih terukur, terutama pencapaian output serta outcome pelatihan. Pemilihan penggunaaan Google Form sebagai kuesioner dirasa dapat lebih menjaring informasi bagi santri dan santriwari yang terkesan pemalu dan sungkan untuk dalam mengeluarkan pendapat secara langsung dalam forum FGD. Dari hasil FGD dan kuesioner, didapatkan indikator keberhasilan sebagai berikut.

Tabel 2. Indikator Keberhasilan\

\begin{tabular}{|c|c|c|c|}
\hline No & Kriteria & Indikator Keberhasilan & Hasil Evaluasi dari Kuesioner \\
\hline 1. & $\begin{array}{l}\text { Partisipasi } \\
\text { Peserta terlihat } \\
\text { sejak masa } \\
\text { prapelatihan, } \\
\text { pelatihan, hingga } \\
\text { pascapelatihan }\end{array}$ & $\begin{array}{l}\text { Prapelatihan: peserta yang mendaftar } \\
\text { cukup banyak. } \\
\text { Pelatihan: semua peserta mengikuti } \\
\text { pelatihan dengan tertib, dan mencatat materi } \\
\text { dengan baik. Santri yang antuasias bertanya } \\
\text { secara langsung maupun tertulis tentang } \\
\text { bahan dan proses pembuatan sabun. } \\
\text { Pascapelatihan: peserta turut serta } \\
\text { mengikuti FGD dan mengisi kuesioner } \\
\text { daring melalui Google Form. }\end{array}$ & $\begin{array}{l}\text { 1) } 100 \% \text { santri menyatakan mengikuti } \\
\text { pelatihan pembuatan sabun atas inisiatif } \\
\text { sendiri. } \\
\text { 2) } 100 \% \text { santri menyatakan memperhatikan } \\
\text { video demonstrasi pembuatan sabun dan } \\
\text { mengikuti pelatihan melalui Zoom dan } \\
\text { praktik pembuatan sabun. } \\
\text { 3) } 100 \% \text { santri menyatakan mengikuti FGD } \\
\text { dan mengisi Google Form. }\end{array}$ \\
\hline 2. & $\begin{array}{lr}\text { Proses } & \text { Pelatihan } \\
\text { dan } & \text { Praktik } \\
\text { Pembuatan } \\
\text { Sabun }\end{array}$ & $\begin{array}{l}\text { Pelatihan: Pelatihan pembuatan sabun dapat } \\
\text { berjalan dengan baik walaupun dilakukan } \\
\text { secara daring dan tidak tatap muka secara } \\
\text { langsung. } \\
\text { Praktik: Koordinator lapangan berperan } \\
\text { serta memantau berjalannya praktik } \\
\text { membuat sabun hingga menghasilkan } \\
\text { outcome sabun. }\end{array}$ & $\begin{array}{l}\text { 4) } 80 \% \text { santri menyatakan proses pelatihan } \\
\text { berlangsung dengan baik, namun kendala } \\
\text { jaringan internet membuat informasi } \\
\text { yang diterima menjadi tidak maksimal. } \\
\text { 5) } 100 \% \text { santri menyatakan koordinator } \\
\text { lapangan berperan dengan baik sebagai } \\
\text { fasilitator dalam praktik pembuatan } \\
\text { sabun. }\end{array}$ \\
\hline 3. & $\begin{array}{l}\text { Pengetahuan } \\
\text { yang diterima }\end{array}$ & $\begin{array}{l}\text { Pengetahuan yang diterima dari proses } \\
\text { pelatihan dapat dipahami, dipraktikkan } \\
\text { secara langsung, dan ditindaklanjuti oleh } \\
\text { para santri secara mandiri. }\end{array}$ & $\begin{array}{l}\text { 6) } 100 \% \text { santri menyatakan belum } \\
\text { mengetahui tentang bahan dan proses } \\
\text { pembuatan sabun } \\
\text { 7) } 100 \% \text { santri bisa menjelaskan bahan- } \\
\text { bahan yang dibutuhkan untuk membuat } \\
\text { sabun. } \\
\text { 8) } 80 \% \text { santri mengetahui tahapan dalam } \\
\text { memaparkan pembuatan sabun dengan } \\
\text { benar. Walaupun terkesan mudah, } \\
\text { namun dalam praktiknya harus } \\
\text { memperhatikan beberapa catatan seperti } \\
\text { berikut: harus hati-hati saat memasukkan } \\
\text { NaOH ke Aquades, dan memperhatikan } \\
\text { keseimbangan suhu saat proses } \\
\text { pencampuran dengan minyak. } \\
\text { 9) santri menyatakan bisa } \\
\text { mempraktikkan pembuatan sabun secara }\end{array}$ \\
\hline
\end{tabular}


158 Penggunaan Teknologi dalam Pelatihan Pembuatan Sabun sebagai Upaya Pemberdayaan Santri Pesantren Darussalam - Sumenep di Masa Pandemi Covid-19- Widhyasmaramurti, Khanifah, Yuni Krisyuningsih Krisnandi

DOI: https://doi.org/10.31004/abdidas.v2i1.232

\begin{tabular}{|c|c|c|c|}
\hline & & & mandiri bila bahannya tersedia. \\
\hline 4. & $\begin{array}{l}\text { Keterampilan } \\
\text { Pascalatihan }\end{array}$ & $\begin{array}{l}\text { Tercapainya output yaitu komunitas santri } \\
\text { yang mampu memproduksi sabun, dan } \\
\text { outcome adalah sabun yang dihasilkan oleh } \\
\text { para santri. }\end{array}$ & $\begin{array}{l}\text { 10) } 100 \% \text { santri menyatakan bersedia } \\
\text { mempraktikkan pembuatan sabun baik } \\
\text { mandiri (individual) maupun bersama- } \\
\text { sama (komunal) sebagai sebuah } \\
\text { komunitas. } \\
\text { 11) } 100 \% \text { santri menyatakan jika mereka } \\
\text { sukses memproduksi sabun. } \\
\end{array}$ \\
\hline 5 & $\begin{array}{lr}\text { Sabun } & \text { hasil } \\
\text { pelatihan dapat } \\
\text { digunakan dan } \\
\text { diperjualbelikan }\end{array}$ & $\begin{array}{l}\text { Sabun hasil pelatihan dapat digunakan oleh } \\
\text { para santri untuk keperluan internal di dalam } \\
\text { lingkungan pesantren dan diperjualbelikan. }\end{array}$ & $\begin{array}{l}\text { 12) } 100 \% \text { santri menyatakan hasil sabun } \\
\text { yang mereka hasilkan terbentuk dengan } \\
\text { baik. } \\
\text { 13) } 25 \% \text { santri menyatakan jika hasil sabun } \\
\text { dapat digunakan oleh para santri di } \\
\text { pesantren untuk mengurangi } \\
\text { pengeluaran di masa pandemi, dan } 75 \% \\
\text { santri menyatakan jika mereka berharap } \\
\text { dapat membuka lapangan pekerjaan } \\
\text { untuk santri-santri lain. } \\
\text { 14) } 25 \% \text { santri menyatakan sabun dapat } \\
\text { diperjualbelikan melalui teman/saudara, } \\
25 \% \text { santri menyatakan sabun dapat } \\
\text { dititip di toko, dan 50\% santri } \\
\text { menyatakan perlunya dijual di e- } \\
\text { commerce. }\end{array}$ \\
\hline
\end{tabular}

Output kegiatan yang dapat terukur adalah tertransformasinya pengetahuan, keterampilan dan afeksi dari Tim Pengmas kepada komunitas santri Pesantren Darussalam sehingga membentuk komunitas santri fasilitator yang mempunyai pengetahuan akan proses pembuatan sabun. Kemudian, outcome yang terukur adalah hasil sabun yang diproduksi. Ada dua jenis sabun yang diproduksi saat praktik yaitu sabun minyak sawit dan sabun minyak jelantah. Sabun minyak sawit dapat dapat digunakan di dalam lingkup pesantren untuk mendukung protokol kesehatan mencuci tangan, sedangkan sabun minyak jelantah untuk mencuci peranti sehati-hari seperti baju dan sepatu. Maka, sabun yang dihasilkan dapat dikatakan sebagai upaya pendukung pencegahan Covid-19, serta dapat menjadi komoditas ekonomi santri Pesantren Darussalam.

\section{Rencana Keberlanjutan Program}

Fokus dari pendampingan kali ini masih ke dalam proses produksi sabun. Hal ini karena pelatihan pembuatan sabun tidak bisa dilakukan secara langsung di lokasi pesantren. Walau demikian, hasil sabun yang diproduksi sudah dapat digunakan secara langsung oleh para santri. Oleh sebab itu, untuk keberlanjutan program, akan difokuskan kepada mengembangkan komunitas santri pembuat sabun dan upaya peningkatan ekonomi santri. Komunitas santri ini nantinya dapat membentuk koperasi santri yang membuat agenda proses produksi, memperhitungkan nilai ekonomi, riset pasar, menjalin mitra, dan mengembangkan pemasaran melalui aplikasi $e$ commerce daring. Apabila proses produksi sudah berjalan secara teratur, maka akan dipersiapkan untuk mengembangkan koperasi pesantren menjadi UMKM di bawah Pemerintah Daerah. 
158 Penggunaan Teknologi dalam Pelatihan Pembuatan Sabun sebagai Upaya Pemberdayaan Santri Pesantren Darussalam - Sumenep di Masa Pandemi Covid-19- Widhyasmaramurti, Khanifah, Yuni Krisyuningsih Krisnandi

DOI: https://doi.org/10.31004/abdidas.v2i1.232

Agenda untuk mengembangkan usaha sabun Pesantren Darussalam menjadi UMKM merupakan suatu hal yang diharapkan dapat turut meningkatkan perekonomian santri Pesantren Darussalam. Walaupun pelaksanaan secara daring telah usai dilakukan, namun proses pendampingan tidak berhenti. Komunikasi untuk terus meningkatkan produksi sabun pesantren akan terus dilakukan baik oleh Tim Pengmas, Koordinator Lapangan, serta para santri Pesantren Darussalam. Komunikasi dapat dilakukan dalam lingkup personal melalui aplikasi komunikasi seperti whatsApp, dan Telegram, maupun secara komunal melalui diskusi daring menggunakan platform Zoom.

\section{SIMPULAN}

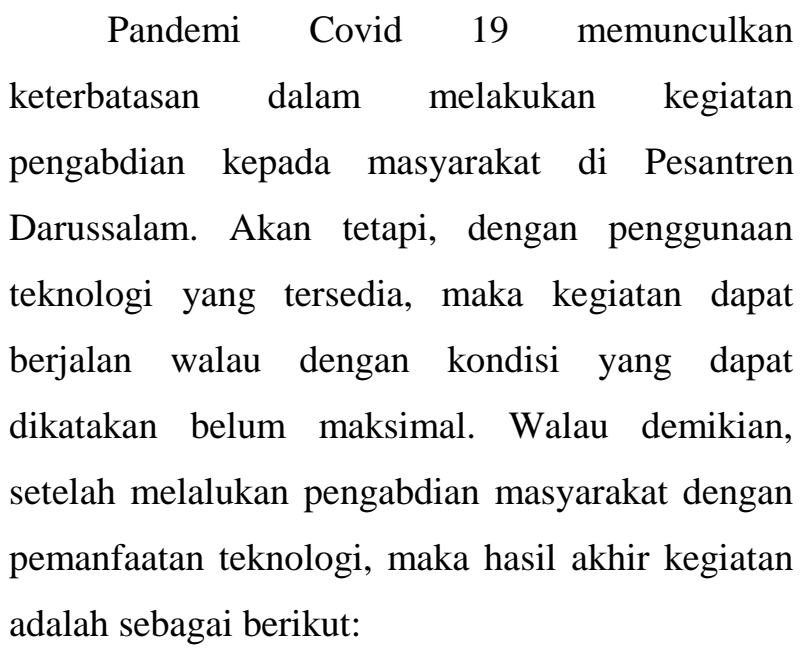

1. Walaupun kondisi jaringan internet yang kurang stabil menjadi tantangan dalam proses pelatihan pembuatan sabun, namun transfer pengetahuan melalui proses pelatihan pembuatan sabun yang dilakukan secara daring tetap dapat terlaksana dengan menggunakan platform Zoom, WhatsApp, dan Google Form. Hal ini karena adanya dukungan dari koordinator lapangan yang juga membantu menjadi pendamping di lokasi selama proses pelatihan berlangsung untuk mengawasi berjalannya kegiatan.

2. Pemberdayaan santri melalui pelatihan pembuatan sabun bukan hanya sebagai proses transfer pengetahuan akan tahapan pembuatan sabun, namun juga sebagai upaya untuk memperkenalkan cara hidup sehat para santri. Sabun dapat dihasilkan dari beragam jenis minyak. Semakin baik kualitas minyak, maka semakin baik hasil sabun yang diproduksi. Saat praktik, para santri menggunakan bahan minyak sawit. Sabun yang dihasilkan dari minyak sawit dapat mendukung gaya hidup sehat para santri karena dapat digunakan untuk mencuci tangan sehingga dapat mendukung protokol kesehatan di lingkup Pesantren Darussalam. Kegiatan Pengmas ini juga membentuk komunitas santri yang mampu menerapkan teknologi tepat guna untuk mengembangkan usaha sabun mereka ke depannya dengan cara ditawarkan melalui proses jaringan ke masyarakat di sekitar santri dan melalui platform digital $e$ commerce.

\section{UCAPAN TERIMAKASIH}

Tim Pengabdian Masyarakat mengucapkan terima kasih kepada Direktorat Pengabdian dan Pemberdayaan Masyarakat Universitas Indonesia yang telah memberikan dana pembiayaan kegiatan 
159 Penggunaan Teknologi dalam Pelatihan Pembuatan Sabun sebagai Upaya Pemberdayaan Santri Pesantren Darussalam - Sumenep di Masa Pandemi Covid-19- Widhyasmaramurti, Khanifah, Yuni Krisyuningsih Krisnandi

DOI: https://doi.org/10.31004/abdidas.v2i1.232

di tahun 2020. Terima kasih juga dihaturkan kepada segenap pengurus Pesantren Darussalam, Sumenep, yang telah berkenan mengurus persiapan pelaksanaan kegiatan di lapangan dengan baik, dan mengatur para santri sehingga mereka dapat mengikuti tahapan kegiatan pelatihan pembuatan sabun secara daring dengan baik.

\section{DAFTAR PUSTAKA}

Ashari, A. (2018). Apa Itu Internet Speed Test? Cari Tahu Fakta Kecepatan Internet, Yuk! Bobo.Grid.Id. https://bobo.grid.id/read/081243169/apa-ituinternet-speed-test-cari-tahu-fakta-kecepataninternet-yuk?page $=$ all

Covid19.go.id. (2021). Beranda | Satgas Penanganan COVID-19. Covid19.Go.Id. https://www.covid19.go.id/

Hanifah Salsabila, U., Irna Sari, L., Haibati Lathif, K., Puji Lestari, A., \& Ayuning, A. (2020). Peran Teknologi Dalam Pembelajaran Di Masa Pandemi Covid-19. Al-Mutharahah: Jurnal Penelitian Dan Kajian Sosial Keagamaan, $\quad 17(2), \quad$ 188-198. https://doi.org/10.46781/al-

mutharahah.v17i2.138

Hudayana, B., Kutanegara, P. M., Setiadi, S., Indiyanto, A., Fauzanafi, Z., Nugraheni, M. D. F., Sushartami, W., \& Yusuf, M. (2019). Participatory Rural Appraisal (PRA) untuk Pengembangan Desa Wisata di Pedukuhan Pucung, Desa Wukirsari, Bantul. Bakti Budaya, 2(2), 3. https://doi.org/10.22146/bb.50890

Kemendikbud, B. K. dan H. M. (2020). Kemendikbud Imbau Pendidik Hadirkan Belajar Menyenangkan Bagi Daerah yang Terapkan Belajar di Rumah. Kemdikbud.Go.Id.

https://www.kemdikbud.go.id/main/blog/202 0/03/kemendikbud-imbau-pendidik-hadirkanbelajar-menyenangkan-bagi-daerah-yangterapkan-belajar-di-rumah
Kurnia, T. (2018). Data Lengkap Jaringan 5 Operator di Indonesia, Siapa Paling Ngebut? Liputan6.Com.

https://www.liputan6.com/tekno/read/355138 8/data-lengkap-jaringan-5-operator-diindonesia-siapa-paling-ngebut

Kurniawan, D. (2020). Respons Wali Kota Surabaya Risma soal Cuitan Cak Imin. Surabaya.Liputan6.Com.

https://surabaya.liputan6.com/read/4182707/r espons-wali-kota-surabaya-risma-soal-cuitancak-imin

Pranita, E. (2021). Pahami Cara Merawat Pasien Covid-19 yang Harus Isolasi Mandiri di Rumah. Kompas.Com. https://www.kompas.com/sains/read/2021/02 /01/170500223/pahami-cara-merawat-pasiencovid-19-yang-harus-isolasi-mandiri-dirumah?page=all

Pratama, K. R. (2020). Alasan Zoom Banyak Dipakai untuk Rapat hingga Kuliah dari Rumah. Tekno.Kompas.Com. https://tekno.kompas.com/read/2020/03/24/0 8020077/alasan-zoom-banyak-dipakai-untukrapat-hingga-kuliah-dari-rumah

Setiawan, S. R. D. (2020). Survey: 84 Persen Masyarakat Akui Pendapatan Turun karena Corona. Kompas.Com. https://money.kompas.com/read/2020/06/26/ 122922726/survei-84-persen-masyarakatakui-pendapatan-turun-karenacorona? page $=$ all

Sispk.bsn.go.id. (2021). Sistem Informasi Standar Nasional Indonesia. Sispk.Bsn.Go.Id. http://sispk.bsn.go.id/SNI/ICS_Detail_list/10 14

Sumenepkab.bps.go.id. (2018). Luas Wilayah Menurut Kecamatan di Kabupaten Sumenep. Sumenepkab.Bps.Go.Id.

https://sumenepkab.bps.go.id/statictable/2014 /03/02/4/luas-wilayah-menurut-kecamatandi-kabupaten-sumenep.html

Sumenepkab.bps.go.id. (2019). Produk Domestik Regional Bruto Kabupaten Sumenep tahun $2019 . \quad$ Sumenepkab.Bps.Go.Id. https://sumenepkab.bps.go.id/statictable/2019 /10/24/40/pdrb-seri-2010-menurutpengeluaran-juta-rupiah-harga-konstan- 
160 Penggunaan Teknologi dalam Pelatihan Pembuatan Sabun sebagai Upaya Pemberdayaan Santri Pesantren Darussalam - Sumenep di Masa Pandemi Covid-19- Widhyasmaramurti, Khanifah, Yuni Krisyuningsih Krisnandi

DOI: https://doi.org/10.31004/abdidas.v2i1.232

2010.html

Sumenepkab.bps.go.id. (2021). Hasil Sensus Penduduk Kabupaten Sumenep.

Sumenepkab.Bps.Go.Id.

https://sumenepkab.bps.go.id/pressrelease/20

21/01/21/101/hasil-sensus-penduduk-

kabupaten-sumenep-.html

Widyasanti, A., S.H., P., \& S. N. P., D. (2016).

Upaya Pemberdayaan Masyarakat Melalui Pelatihan Pembuatan Produk Sabun Berbasis Komoditas Lokal Di Kecamatan Sukamantri Ciamis. Jurnal Aplikasi Ipteks Untuk Masyarakat, 5(1), 29-33. 